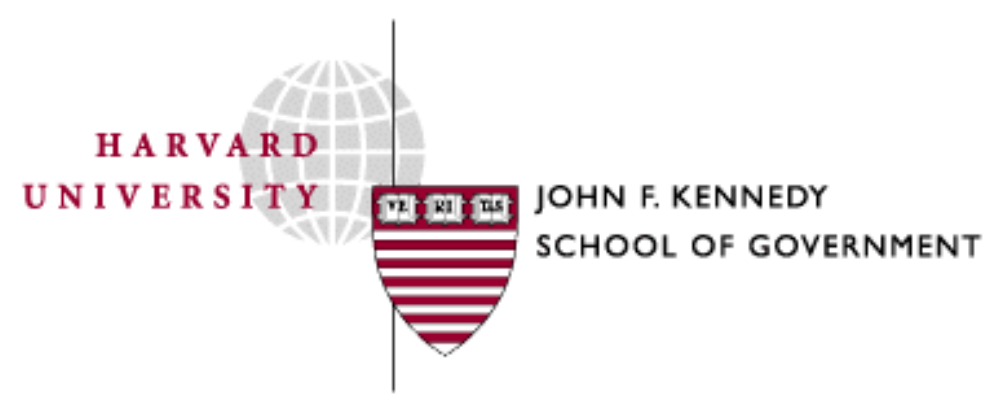

Faculty Research Working Papers Series

Fairness, Export Subsidies, and the Fair Trade Movement

Malgorzata Kurjanska

Harvard University

Mathias Risse

John F. Kennedy School of Government

Harvard University

June 2006

RWP06-023

The views expressed in the KSG Faculty Research Working Paper Series are those of the author(s) and do not necessarily reflect those of the John F. Kennedy School of Government or Harvard University. Copyright belongs to the author(s). Papers may be downloaded for personal use only. 


\title{
Fairness, Export Subsidies, and the Fair Trade Movement
}

\author{
Malgorzata Kurjanska and Mathias Risse, Harvard University
}

June 23, 2006

1. One of the more striking parts of the Communist Manifesto is the description of the global spread of capitalism, a description that could easily be taken to refer to developments of the last decades. According to Marx and Engels, the

bourgeoisie has through its exploitation of the world-market given a cosmopolitan character to production and consumption in every country... All old-established national industries have been destroyed or are daily being destroyed. ... In place of the old wants, satisfied by the productions of the country, we find new wants, requiring for their satisfaction the products of distant lands and climes. In place of the old local and national seclusion we have intercourse in every direction, universal interdependence of nations. (p 148f)

Yet Marx and Engels did not anticipate that global capitalism would eventually be overseen by a network of organizations, including one concerned with trade (the World Trade Organization, WTO). The globalization of trade and the creation of the WTO have attracted much attention to questions of fairness in trade. This study aims to address two central issues prominent in that debate that are interrelated in interesting ways: agricultural subsidies and the Fair Trade movement. ${ }^{1}$

For years, agricultural subsidies in the US, the EU, and Japan have been summoned for debate. Their existence is widely regarded as indicating the unwillingness of these countries to

\footnotetext{
${ }^{1}$ This study is a continuation of the research begun in Risse (forthcoming). That paper also offers a general account of fairness and shows how it applies to trade. Here we will refrain from doing so and discuss the two topics of this study in a way that spells out directly what the considerations are that bear on their fairness or unfairness. Some of the discussion of subsidies also relies on that earlier piece; what is new, in addition to an expansion of the discussion of subsidies, is the exploration of the interconnections between issues about subsidies and issues about the Fair Trade movement, as well as a discussion of that movement itself. We will refer to the "Fair Trade movement" in capital letters because it is a fairly well-defined movement with certain goals; we are not thereby committing ourselves to endorsing their concerns as fair. Like Risse (forthcoming), this paper assumes the legitimacy of states of varying size and power. Issues about fairness in trade take on a very different shape if one opposes that view.
} 
design the trading system for the benefit of the poor. Even globalization proponents target subsidies in that spirit. According to Wolf (2004),

total assistance to rich country farmers was $\$ 311$ billion in 2001, six times as much as all development assistance, indeed more than the GDP of Sub-Saharan Africa. In 2000, the EU provided $\$ 913$ for each cow and $\$ 8$ to each Sub-Saharan African. The Japanese, more generous still, though only to cows, provided $\$ 2,700$ for each one and just $\$ 1.47$ to each African. Not to be outdone, the US spent \$10.7 million a day on cotton and \$3.1 million a day on all aid to Sub-Saharan Africa. (p 215) ${ }^{2}$

Wolf concludes that "the priorities shown here are obscene." Similarly, Oxfam accuses developed countries of applying double-standards: while they insist that developing nations liberalize trade, they continue to protect their own economies. "Nowhere,” Oxfam says,

are the double standards of industrialized-country governments more apparent than in agriculture. Total subsidies to domestic farmers in these countries amount to more than $\$ 1$ billion a day. These subsidies, the benefits of which accrue almost entirely to the wealthiest farmers, cause massive environmental damage. They also generate overproduction. The resulting surpluses are dumped on world markets with the help of yet more subsidies, financed by taxpayers and consumers. (Oxfam (2002), p 11)

The same Oxfam report praises the Fair Trade movement as one of the most powerful responses to problems facing commodity producers. It aims to give consumers an opportunity to use their purchasing power to tilt the balance, however slightly, in favor of the poor (p 165).

The relationship between subsidies and Fair Trade is worth exploring in detail. The view emerging from the Oxfam report is widespread: support for Fair Trade is called for, whereas agricultural subsidies are unjustifiable. Yet there are curious similarities between these scenarios. On the face of it, both subsidies and Fair Trade concern producers who are to be supported beyond what the market would sustain. In both cases arguments on behalf of such producers can take on two forms. First, such arguments might be presented as claims of producers. In the case of agricultural subsidies, farmers in developed countries assert claims against their fellow

\footnotetext{
2 Anderson (2004), p 349f, says agricultural subsidies account for $38 \%$ of governmental expenditures on subsidies between 1994 and 1998.
} 
citizens, who ought to accept redistributive measures to keep them in business. In the case of Fair Trade, the claim can be made by farmers in developing nations against consumers, who ought to pay higher prices to keep them in business (under conditions deemed acceptable). Second, arguments to keep producers in business might be presented as the prerogative of both groups: even if farmers in developed countries did not have a claim to be kept in business, these countries would have the right to take measures to do so because they value their products. Similarly, in the case of Fair Trade, even if farmers in developing nations had no claim against consumers, it is a consumer prerogative to pay more to keep them in business. ${ }^{3}$

Both lines of arguments would have to be defended against competing claims. To wit: claims on behalf of farmers in developed countries must be justified in light of claims of developing countries that subsidies keep them out of the market. A complication stems from the fact that, while subsidies benefit producers in developed countries at the expense of domestic consumers, they benefit consumers in countries that are net-importers of the good in question while harming producers abroad. Since moreover developing countries often subsidize products, subsidies are ill-understood as a show-down between "rich" and "poor." Claims on behalf of farmers in developing countries must be justified against the view that supporting Fair Trade is detrimental to development efforts of poor countries as a whole, efforts whose goal should be to explore what countries are comparatively good at producing, rather than to maintain the production of things at which they are not competitive after all. Fair Trade needs to fend off the claim that it stands in the way of sustainable development.

\footnotetext{
${ }^{3}$ We will often refer to these arguments as the claims-based argument and the collective-preference-based argument, respectively. That is a bit misleading in the sense that the latter also involves a claim, namely, a claim by the collectivity that holds this preference. But in light of the explanation of the arguments given above, we hope this will not lead to any confusion.
} 
Of course, there are important differences between these two scenarios. For one, export subsidies are paid by governments and thus regulated by central authorities, whereas Fair Trade appeals to individuals' purchasing choices. Further, the economic impact of subsidies is much higher than the impact of Fair Trade. Nevertheless, it should be clear not only that it is worth our while taking a closer look at the arguments for and against subsidies as well as for and against supporting Fair Trade, but also that it will be illuminating to discuss these topics together.

2. We begin by discussing subsidies. Economic globalization and the global market are often praised as forces of social improvement and poverty reduction. A core element in such globalization is the idea of comparative advantage. A country has a comparative advantage in a commodity if it has a lower opportunity cost of its production than the opportunity cost of another nation. If country A is better at producing cheese than at producing wine, it should obtain wine by specializing in cheese while trading some of it for wine. If the reverse is true for $\mathrm{B}$, or if using the same resources B would have produced less cheese than A anyway, B should trade wine for cheese. A has a comparative advantage in cheese and B in wine, even if $\mathrm{A}$ is better at (has an absolute advantage in) producing both or both are equally good in producing wine. ${ }^{4}$

Export subsidies are governmental payments made to producers for exporting products. By definition, such subsidies benefit domestic producers. They harm consumers because there are fewer goods on the domestic market, and thus their prices rise. While redistributing wealth to producers, subsidies also cause "deadweight-losses," distortions arising because restrictions

\footnotetext{
${ }^{4}$ There are additional benefits to trading, in particular the fact that larger markets allow for economies of scale and that competition improves efficiency. Cf. Krugman and Obstfeld (2003) for an introduction to international economics; cf. Hoekman and Kostecki (2001) on the trading system; cf. Trebilcock and Howse (2005) on the regulation of international trade. Cf. Stiglitz and Charlton (2005), chapter 2, for difficulties in applying the idea of comparative advantage to economic scenarios (which especially involve transition problems and applications to scenarios with particularly pronounced market failures). Cf. Bhagwati (1993) for objections to free trade. For the importance of experimenting to development, cf. Hausmann and Rodrik (2003).
} 
motivate producers to produce more and consumers to consume less than they otherwise would. As Irwin (2002), p 55, reports, the US sugar price is twice that of the world market. Producers receive about $\$ 1$ billion annually, of which $42 \%$ go to $1 \%$ of farms. The costs of protection amount to 1.9 billion, .9 billion being deadweight losses. Subsidies also have effects abroad. They harm producers elsewhere by lowering world market prices (assuming subsidies are large enough to affect these prices), leading to lower wages and limiting employment possibilities. Ipso facto, subsidies benefit consumers elsewhere (though these may in the end be the same people who lose work because producers cannot hire them). For instance, agricultural subsidies benefit consumers in net-food-importing nations, which as of 1999 include 45 of the 49 leastdeveloped countries (Panagariya (2003), p 22). ${ }^{5}$

Subsidies create a particular situation on the world market that, at the level of countries, works to the benefit of some and to the detriment of others, where often the way in which individuals fare respectively depends on whether they are producers or consumers. When the Multi-Fiber-Agreement was discontinued (which had regulated the markets in textiles), a new situation was created on the textile market from which especially China benefited enormously. ${ }^{6}$

\footnotetext{
${ }^{5}$ For net-food-importers, see Hoekman and Kostecki (2001), pp 225 ff. One should be careful not to make too much of the value of this argument in support of export subsidies. Individuals in developing nations lack food security fundamentally because they "lack buying power," i.e., employment or sufficient income. Furthermore, the lack of food production in developing countries that are importers (though they have a comparative advantage in the cost of labor and ought to be able to match global agricultural prices) is possibly already a result of the international "price signals" (of subsidy depressed prices) which may provide disincentives for necessary investment in a developing nation's agricultural development (cf. Ingco and Nash (2004)). So the productive inabilities of a developing nation that are a result of its current state of development and poverty make for dubious support to continue international practices that contribute to the lack of incentives and aid to propel institutional and productive development.

${ }^{6}$ The anticipation of the end of the Multi-Fiber Agreement led textile companies to shift their production to developing nations, largely to China (because of its large supplies of low wage labor). As a result of the ending of the agreement, developed and some developing nations experienced a collapse of their textile industries and an influx of goods imported from China and some other nations, like India. (For recent reporting on this, cf. "Trading Down,” Nation, 1/10/2005, Vol. 280 Issue 2, p4-5, 2p; “Protection Racket,” New Republic, 4/25/2005, Vol. 232 Issue 15, p7-7, 1p; “Ten Years to Plan for Trade Changes, and Still EU Failed to Prepare” The Independent (London). 8/27/2005, $1^{\text {st }}$ Ed, News p. 2).
} 
Retrospectively we see that the Multi-Fiber-Agreement supported its beneficiaries against competition from China. At the time, this was not observed because China lacked the opportunity to develop its potential in this field. Similarly, if subsidies were to be removed, opportunities would arise for some countries to gain an advantage in agriculture, causing some to alter what they produce. Yet it is difficult to predict which countries would make the shift. There are few incentives for countries to explore possible exporting agricultural products in which they would have a comparative advantage if subsidies were removed. Agricultural liberalization may not benefit the nations on behalf of which it is often demanded.

Subsidies create winners and losers, and their removal would as well. Nevertheless, it has been argued that, from a consequentialist point of view, the case for trade liberalization (and against subsidies) is straightforward, or at any rate, that the economic case for liberalization is overwhelming. Following Anderson (2004), p 550, estimated gains from liberalization range from $\$ 254$ billion annually (\$108 billion for non-OECD countries, in 1995 dollars), to $\$ 832$ billion (\$539 billion for non-OECD countries, 1997 dollars), depending on how the estimates are made. (These are estimates of full trade liberalization, not merely by rich countries, which primarily benefits their consumers.) Anderson and Martin (2006b) say that "[f]reeing all merchandise trade and eliminating agricultural subsidies are estimated to boost global welfare by nearly $\$ 300$ billion a year by 2015. Additional gains would come from whatever productivity effects that reform would generate” ( $p$ 11). They add that $45 \%$ of the gains would go to developing countries, which would be above their one-fifth share of global GDP.

However, such estimates vary widely pending on the predictive model. Hertel and Keeney (2006) estimate that eliminating agricultural subsidies and liberalizing trade in goods and 
services would lead to gains of $\$ 151$ billion, $\$ 34$ billion for developing countries. ${ }^{7}$ Others claim that the importance of removing especially agricultural subsidies has been exaggerated (e.g., Birdsall et al. (2005)) and that other development programs would produce significantly higher gains (especially a temporary work permit program). ${ }^{8}$ Yet our concern is not primarily with consequentialist arguments for liberalization, but with an investigation of the moral force of claims people may make to subsidies. Our standpoint is a non-consequentialist one. In light of the fact that subsidies, just like their removal, create winners and losers, we can expect an inquiry into the sources of such claims to be philosophically non-trivial. ${ }^{9}$

3. Can some people make a case that their government ought to support them although this is not in the country's overall economic interest? Although the general thrust of consequentialist arguments goes against subsidies, there are some such arguments that give an affirmative answer, especially the infant-industries argument. That is, the claim that trade liberalization is always good and subsidies, like other trade-constraining measures, are always bad, may well require some qualification, even from a consequentialist standpoint. ${ }^{10}$ However, again, our concern is with the question of whether people might have non-consequentialist claims to subsidies. From such a standpoint, one might defend subsidies in two ways. First, one might argue that some people have a claim against their fellow citizens to be allowed to continue in a certain line of work, although it is no longer profitable. Farmers in the US or the EU could make

\footnotetext{
${ }^{7}$ Curiously, Hertel and Keeney (2006) and Anderson and Martin (2000b), offering these vastly different estimates, both appear in Anderson and Martin (2006a).

${ }^{8}$ For a discussion of the impact of trade on poverty, cf. Winters et al. (2004).

${ }^{9}$ There is more to say about the relevant consequentialist considerations. So far we have merely talked about financial benefits from liberalization. But we set such matters aside.

${ }^{10}$ See Stiglitz and Charlon (2006), chapter 2; cf. also Stiglitz (2002), chapter 3.
} 
such a claim. What would drive the claim is that such support is owed them qua fellow citizens. Second, one might argue that it is the political community as a whole that has the prerogative to indulge in certain products (say, products grown on their soil), and to pay subsidies to farmers if this is what it takes to keep them in business - regardless of whether such payments harm farmers elsewhere.

To investigate the former argument (i.e., whether individuals have claims against their fellow citizens), we assume a liberal-egalitarian framework, specifically a Rawlsian society (cf. Rawls (1999), and Rawls (2001) for an introduction). In the end, we want to argue that such claims can be defeated, and thus we adopt a framework friendly to them. Within this framework, individuals have a claim to governmental services. Governments must strive to realize the principles of justice: they must ensure that basic liberties are respected, that the basic structure of society is arranged so that there is fair equality of opportunity of access to positions of influence and power, and that remaining socio-economic inequalities benefit the least-advantaged.

The claim that governments must strive to realize the principles of justice moves at a high level of abstraction, and Rawls envisages a four-stage sequence of implementation, starting from the Original Position via a constitutional and legislative stage to judicial enforcement. A claim to subsidies is a very specific claim to continue in a chosen line of work although granting the claim is detrimental to the economy. It is much stronger than a claim to basic economic protection, which could be provided in many forms, for instance, through unemployment benefits or funds to enter a different line of work. For claims to subsidies to succeed, individuals must argue that the government can be liable for their choice of occupation (and so for the consequences of this choice turning out to be an unfortunate one). An argument to this effect cannot be that the absence of subsidies would harm some people, perhaps only in the sense that it 
would disadvantage them relative to others; most government measures are of that nature, which by itself provides no claim to governmental action. A specific argument is needed for why the government would be under an obligation if occupational choices turn out badly.

On the face of it, it would appear implausible that individuals have these particular claims. One might think everybody is on the labor market at their own risk (except that a social system provides basic safeguards) and for their own sake (except that they must help maintain the basic structure of society through paying taxes). They acquire skills, and if they succeed, they get to keep the gains, such as salaries and other benefits (except for taxes); if they fail, all the state owes them is general protection against economic hardship. This indeed is the view of participation implicit in the political economy of a liberal market system. However, as the Varieties-of-Capitalism approach to comparative political economy shows, different versions of capitalism have arisen across countries. Moreover, different versions of capitalism are consistent with the Rawlsian framework, in much the same way in which Rawls notes that different property regimes are compatible with it (cf. Rawls (2001), sections 41 and 42).

Different versions of capitalism are characterized by institutional complementarities: one set of institutions operates effectively only (or more effectively) if accompanied by other institutions, which concerns especially the ownership of companies and labor markets. Two ideal types are liberal market economies, as present for instance in the US, and coordinated market economies, as present for instance in Germany. What matters for us is that coordinated economies have rigid labor markets that encourage employees to invest heavily into specialized skills and reward them with job security. Other factors that shape the political economy complement such labor markets. As the particular modes of complementarity do not matter for our purposes, we will not address them any further. Crucially, participants in a coordinated 
economy have a different relationship to the state than they do in a liberal economy. ${ }^{11}$ As an illustration, notice the following assessment of labor markets in Germany and Japan:

Social constraints and opportunities (...) typically enforced by social institutions, define the legitimate place and the possible range of market transactions and markets in the economy-cum-society in which they take place. By circumscribing and thereby limiting the role of markets, they typically 'distort' them, for example by shielding desirable social conditions from market fluctuations” (Streeck and Yamamura (2001), p 2).

Since workers specialized because legislation made it irrational for them not to do so, they may claim that the state should be liable for their line of work and its possible demise. To relate this back to the Rawlsian framework: What grounds general redistributive duties is the coercive framework that all citizens share, and what grounds this particular duty to subsidies is the specific shape the political economy has taken. ${ }^{12}$ Through legislation, a government in a coordinated market economy has framed its social involvement, and thus its social responsibility, in a certain way. By taking an active role in promoting and supporting specialization, the government has marked itself as an active player in its citizens’ professional decisions. The risk that accompanies such heavy specialization, if occurring in response to the way labor markets are framed, is justifiable to citizens only if the state offers guarantees in case they fail. This is not to say governments ought to take on such a responsibility. Rather, it is to point out that in coordinated market economies they have done so.

As opposed to this, in liberal market economies individuals' employment decisions are more their own: they specialize, or fail to specialize, at their own risk. Under such conditions it is harder to see how market participants could get a claim to subsidies to continue in a line of work. Even in such systems the state is doing a lot to "subsidize" individuals: it provides the

\footnotetext{
${ }^{11}$ For the Varieties-of-Capitalism approach, cf. Hall and Soskice (2001); for a review of the area, cf. Howell (2003).

${ }^{12}$ For this reading of Rawls, see Blake (2001).
} 
institutional background that enables individuals to live their lives and pursue career goals. Often such support includes funding for research and development that affects their ability to perform well in the global economy, not to mention support for schooling and infrastructure. Yet support for lines of work that, even under such conditions, turn out to be unprofitable is beyond the limits to what individuals have claims.

4. Even in a coordinated economy one may doubt whether participants have sufficiently strong claims for the state to be obligated to enable them to continue in their chosen line of work. Plausibly, the strength of claims of participants in such economies depends on the difficulty of finding other employment, or more generally, on the costs for the affected individuals. For instance, Watkins and Sul (2002) argue that cotton subsidies mostly benefit large farms that could easily grow other crops. Our argument does little to support claims of such farmers. ${ }^{13}$

Even under the most favorable conditions for this sort of argument to succeed (i.e., with other possible constraints in place) doubts may persist. One may say that at best this argument can show that employees have a claim to a high level of governmental support. What is harder to maintain is that such support will have to take the specific form of ongoing support in a line of business that is in the nation's interest to discontinue. Often claims to a high level of support will turn into a claim to aid to continue in one's line of work, if the costs of change are too high for

\footnotetext{
${ }^{13}$ Note the following account of how farm subsidies arose in the US: "Later that year [1934], the government men offered contracts to wheat farmers if they agreed not do plant next year. This idea seemed immoral and not the least a bit odd to people when they first heard about it. Like the cattle slaughters, it was part of a Roosevelt initiative to bring farm prices up by reducing supply - forced scarcity. In the end, many farmers were not going to plant anyway - what was the use with no water? --- so the idea that they could get money by agreeing to grow nothing was not a hard sell. More than twelve hundred wheat farmers in No Man's Land signed up for contracts and in turn got a total of $\$ 642,637$ - an average of $\$ 498$ a farmer. Thus was born a subsidy system that grew into one of the untouchable pillars of the federal budget. It was designed for poor grain growers, one foot in foreclosure, near starvation, pounded by dirt. And plenty of farmers were starving” (Egan (2006), p 158). This occurred during the Great Dustbowl, when massive dust storms befell the interior of the US, eroding the soil and causing great hardship.
} 
individuals. But there might be competing considerations that discourage the state from satisfying its obligations by making it possible for citizens to stay on in an unprofitable line of work, to wit, if such support bears on other duties of the state. ${ }^{14}$

Before elaborating this further, let us look at a second strategy for supporting the view that certain people should be allowed to continue in a chosen line of work although the market would not allow it. As we saw, subsidies do not merely redistribute, but generate net-losses. Yet a country might consider this the price to pay for having certain products made "at home." For instance, the French might overwhelmingly agree that redistribution to producers as well as deadweight losses are appropriate if needed to continue the production of baguette from French grain, camembert from the milk of French cows, and foie gras from French ducks and geese. Far from honoring an obligation because the political economy made it irrational for farmers not to specialize, the French might have a collective preference for home-grown products, be willing to pay the price for them, and assert that they are entitled to such indulgence.

However, both the individual-claims-based argument and the collective-preference-based argument face the same difficulty, at least under two assumptions. Suppose first that minimal duties of developed towards developing countries apply. There are different reasons for endorsing such duties: because needs compel us to meet them; because in a suitable global Rawlsian original position such duties would be acknowledged; because humanity jointly owns

\footnotetext{
${ }^{14}$ The competing considerations we have in mind are primarily moral, but there are also important political considerations that are raised by subsidies. As the quote form Egan (2006) above already made clear, subsidies, once in place, are difficult to remove. For an example of this phenomenon in a coordinated market economy, cf. Kröhnert et al. (2006, p 122, re. the subsidies for coal mining in the Ruhr area in Germany. Subsidies for the coal industry were originally intended to facilitate the transition of a generation of coal miners into new jobs. But once in place, subsidies were kept up by a lobby of politicians, trade union functionaries, and industrialists, who continued to hire new miners whose presence was then used to exert more pressure on the federal and state government to obtain more subsidies. As a result, since 1980, Germany has spent about 100 billion Euro on such subsidies. These subsidies could not save the coal industry in the Ruhr area, but prevented local cities from developing economically sensible alternatives. As a result, the Ruhr area is now stricken by severe economic and demographic problems.
} 
the earth and must ensure everybody gets their share; because one cannot consistently endorse certain institutional standards for one's country without assisting others to realize them, etc. At this stage, there is no need to explore such views. Suppose, second, that trade plays a crucial role for growth as well as for other desirable goals of development, such as those listed as the U.N. Millennium Goals. (More on the nature of this link will be said below.) Then trade-liberalization becomes mandatory for developed countries. ${ }^{15}$ On any account of duties to developing countries, links between trade and growth and growth and other goals make an overwhelming case for helping developing countries to join world markets. In that case, measures to keep people in positions whose maintenance contributes to the plight of the poor become unacceptable. This point concerns both the individual-claims-based argument and the collective-preference-based argument.

5. Empirical questions are at the core of this argument, and they continue to be controversial. The crucial point is indeed the link between trade on the one hand and growth and other goals of development on the other. If trade is not tied to these purposes, it will not bear on the satisfaction of duties to developing countries. To adopt a more suitable formulation, it is only to the extent that trade is tied to these purposes that it bears on the satisfaction of duties to developing

\footnotetext{
15 The U.N. Millennium Goals, which are to be reached by 2015 are the following: to cut in half the proportion of people in extreme poverty; universal primary education and gender equality in education; a three-fourths decline in maternal mortality and a two-thirds decline in mortality among children under five; to reverse the spread of HIV/AIDS and to assist AIDS orphans; to improve the lives of 100 million slum dwellers. Cf. U.N. site for a progress report: http://www.un.org/millenniumgoals/index.html. What about developing countries? It lies in the logic of this first point that it applies in between two groups of countries such that one group has duties of aid to the other. So it does not apply among the most developed countries, or among the least developed countries. There will be a gray zone where it is less clear what sort of duties countries have, consisting of economies that are neither among the developed nor among the least developed countries. But the most interesting case is what developed countries should do vis-à-vis the least developed countries.
} 
countries. (It is only to the extent that trade matters for growth and other goals that subsidies pose a moral problem.) How plausible is this link?

Trade theory recommends liberalizing trade since doing so benefits participating countries, even unilaterally. Much of the evidence seems to support this view. Many economists think trade liberalization is necessary, though not sufficient, for fast growth-not sufficient, for if credible policies, enforceable contracts, and other hallmarks of stability are absent, openness cannot trigger sustainable growth. ${ }^{16}$ Yet there is disagreement about just how important trade and liberalization are, and thus about how much priority should be put politically on negotiations to reduce trade barriers, rather than to explore alternative solutions. Those who think institutions are essential for development emphasize domestic reform, fearing that too much political attention paid to trade negotiations distracts from the sort of reform that is really needed. ${ }^{17}$

The ongoing nature of this dispute makes it hard to reach a bottom-line judgment about subsidies. We saw that, in coordinated market economies, individuals do have some claim to support from the government in case their line of work fails. However, we also saw that it depends on the presence of competing claims whether this claim takes on the shape of subsidies. One competing claim is if subsidies are trade-distorting in ways in which other forms of support for citizens in dire straits are not. In such cases it would be appropriate to argue that proportionate consideration of the different claims requires that citizens be helped in minimally

\footnotetext{
${ }^{16}$ Cf. the survey by USITC (1997). Cf. Wacziarg and Welch (2003) and the discussion of the literature in Anderson (2004), p 343f. See also Panagariya (2004a) and Panagariya (2004b). Rodriguez and Rodrik (2000) agree that there is a positive relationship between trade and growth, but question whether it is due to trade policy, rather than transport costs or demand.

${ }^{17}$ Cf. Birdsall et al. (2005) for a concise statement of that view; cf. also Panagarya (2005). We are here glancing over the details of what it means to be important for development. Trade could connected merely to growth, but neither trade nor growth may immediately be tied to other development goals. See, however, the Human Development Report 2003, and the 2004 World Development Indicators and references therein, for arguments that growth is relevantly related to other development goals.
} 
trade-distorting ways. However, the need to avoid trade-distorting measures in turn derives its plausibility from the importance of trade for development. The case for the moral urgency of the termination of subsidies depends on this debate about the importance of trade for development.

There is one more complication. Suppose the relevance of trade for development is strong enough that the claim is warranted that developing countries should abolish trade-distorting subsidies, especially in agriculture. Yet subsidies for producers in developed countries also subsidize net-food-importing countries. If the relevance of trade for development makes it compelling to abolish subsidies, this is so because of the aggregative importance of trade for development, not because this will be good in the short run for each country. At the onset, netfood-importers will find themselves at a disadvantage compared to the situation on the world market with subsidies in place. So if subsidies are discontinued because of the importance of trade for development, such gains will have to be redistributed to countries that suffer in the process. This will cause a grave political problem because those gains do not arise in bank accounts of an international agency that could immediately redistribute them. Instead, these gains will be widely disseminated. Yet to the extent that the discontinuation of subsidies is morally required in light of the importance of trade for development, this problem will need to be solved, and doing so will be politically non-trivial. We cannot offer a proposal for how to do it.

6. Returning to the collective-preference-based argument, a preference for home-grown products could be realized in a manner that is not trade-distorting and thus does not have detrimental effects on people towards whom the French (to remain with our example) have a duty of aid. French farm products could be transformed into gourmet products marketed at a price not affected by subsidies to farmers. Instead, what would have to keep farmers in business would be 
higher prices for the quality of being “French.” In turn, consumers would have to value the latter enough to pay more. ${ }^{18}$ If a collective preference for home-grown food exists, a gourmet market can arise. In that case, the preference could be realized without harm inflicted on producers in developing countries (but also without the benefits for net-food-importing developing countries).

So the French could realize a preference for home-grown products without subsidies. ${ }^{19}$ Yet the existence of subsidies indicates that the French government considers this preference one that should be maintained through government authority, rather than consumer choices. From this one might want to conclude that this argument in support of subsidies is weak. We just discussed an argument that assessed the relative strength of claims of workers and producers in coordinated economies against their governments vis-à-vis claims of developing countries. We saw that claims of workers and producers in developed countries must be given independent weight. However, one might say, this does not seem to be true for a preference for certain foods given that (a) if there is such a preference it could be realized through consumer choices, and that (b) there is no independent moral value attached to such a food-related preference.

Yet the trouble with so concluding is that a collective-preference-based argument for food subsidies is in its policy-implications identical to preferences that may not appear as frivolous as this. One might say that the preservation of French food is part of the preservation of French culture, or part and parcel with preserving the countryside - and these seem to be goals

\footnotetext{
${ }^{18}$ One might say that this reasoning is curious because subsidies keep prices on the domestic market high. What will presumably happen is this. Subsidies are taken away. French products will become less expensive on the home market, but will become more expensive abroad. At the same time, other producers will enter the French market and beat the prices of French producers. So they go out of business unless they can create a market for gourmet products.

19 The failure of the "buy American movement” suggests that consumers may not support expensive goods for their nationalist quality. Fearing job loss in the U.S. "Buy American" campaigns were promoted by labor unions and domestic industries, such as the steel and car industries. Though the movement aimed to muster support to prevent losses of American jobs for workers overseas, it had little effect on the situation (cf. Frank (1999). However, this would be an open question based on the good and community involved.
} 
that do warrant governmental protection. In other cases a country might attach great importance to self-sufficiency on security grounds. Efforts towards the preservation of culture and countryside arguably must be protected by the state because - although these are independently valuable goals - they would otherwise fall prey to a collective action problem. It seems we were dismissive of this collective-preference-based argument by under-describing the extent to which this preference is tied to something of moral value. This takes us back to the end of the discussion of the claims-based argument. That is, to the extent, again, that trade is relevant to development, there is pressure to make sure goals for which the French have collective preferences, that have independent moral value and that should not be left to consumer choices are protected in ways that are not trade-distorting. That argument comes with the same qualifications as the claims-based argument above.

7. Let us turn to Fair Trade. This movement arose in response to falling commodity prices and consists of organizations concerned with improving the situation of commodity and handicraft producers (e.g., International Federation of Free Trade Initiatives, European Fair Trade Association, Transfair International, TransFair USA, Max Havelaar Foundation). Oxfam (2002), p 151, reports that in 2000, prices for 18 major export commodities were $25 \%$ lower in real terms than in 1980. For cocoa, coffee, lead, palm oil, rice, sugar, and tin the decline exceeded 50\%. According to Jaffee et al. (2004), common criteria for obtaining the "Fair Trade" label are these: “fair” prices paid to producers as well as "fair” wages to laborers, which tends to mean prices and wages sufficient to make a living; financial and technical assistance given to producers; insistence on certain standards for the work place; long-term trading relationships; engagement of cooperative in community development and environmentally sustainable production. Fair 
Trade combines different concerns, and it depends on the product which of them stands in the foreground. In respect to products largely grown by small farmers, price is the concern. If the product is grown on large estates, the focus falls on wages and working conditions. ${ }^{20}$

Fair Trade producers in the developing world, like subsidized farmers in the developed world, are asking for support to stay on in a line of business that the market itself does not support. Parallel to the case of subsidies, there are two arguments in favor of Fair Trade, a claims-based and a collective-preference-based argument. First, one can assert that farmers have a claim to support, this time against customers of their products. Second, one can argue that, even if producers are denied their claim, it is a customer's prerogative to pay higher prices than dictated by the market so that producers can carry on (under conditions deemed acceptable). Yet there are also important differences between these scenarios. In particular, the transfer of money involved in Fair Trade functions on a radically smaller scale than that involved in subsidies. Such differences pose limits on how far one should press the parallels. ${ }^{21}$

Often, Fair Trade products are high quality products. For instance, Fair Trade coffee tends to be grown under especially favorable conditions. To the extent that such products command higher prices than the average version of that commodity because they are better, our questions do not arise. We are concerned with assessing whether there is a sense in which customers ought to pay more because goods are produced or distributed under conditions that are morally more commendable than others. Fair Trade often advertises for its products under all

${ }^{20}$ On Fair Trade, cf. Leclair (2002) and Littrell and Dickson (1999).

${ }^{21}$ We do not think that the miniscule impact of any individual contribution to Fair Trade (or the world economy) renders the question of its ethical significance irrelevant. The reasoning that "an individual's contribution is minuscule and therefore it does not matter what an individual does either way" will look appealing at most to consequentialists, and even for them ultimately does not succeed (cf. Parfit (1984), chapter 3, and Shelly Kagan's work-in-progress “Do I Make a Difference?”). 
these aspects. Yet for our analysis, we are assuming these products are not simply better coffee, cocoa, tea, etc., and not merely distributed differently from what is common.

Let us begin our discussion of Fair Trade with a challenge that arguments in support of it must address. At first sight, there seem to be two views of how Fair Trade might be concerned with fairness, and thus of the nature of the duty that might be involved in a customer's buying Fair Trade products. Yet we will see that a unified view of this matter emerges. On that view, there is a broad range of cases in which consumers, when deciding what to buy, will have to think of Fair Trade as one strategy of sustainable development, which it may turn out not to be. In light of these cases, defenders of Fair Trade are challenged to explain how, or when, Fair Trade can be such a strategy. Our next task will be to assess how arguments on behalf of Fair Trade are affected by this challenge.

According to the first view, trade relations per se do not create obligations. Instead, there are general duties towards the poor, and everybody should contribute to their realization in ways available to them. Trade is one way of doing so. Since people drink coffee, buy handicraft and consume other commodities, such purchases offer opportunities to do so. The nature of this duty does not matter for us: there might be a duty to satisfy people's needs, or other positive duties to aid, or a duty of rectifying injustices from which buyers have benefited, etc. There is nothing special about our relationship with those who produce what we consume, or others involved with us in trade. Our duties towards such people are the same duties we have towards others: we have these duties because those people are poor, because we have harmed them, or because we benefit from their being harmed, etc., not because we trade with them.

According to the second view, trade as such brings about a duty for its participants: to ensure either that producers get a certain proportion of the gains from trade (a relative standard), 
or that the process of commodity production and the standard of living of its producers is decent (an absolute standard). On this view, being involved in trade means having a relationship that is special from a moral standpoint in the sense that it creates specific associational duties. Yet in this general version, this view is implausible. A minor concern is this. If Fair Trade products are of comparable quality to other products, Fair Trade consumers pay more than the market price, a consumer-based subsidy that might seem unfair. For it means giving some producers more than others for the same product. Thereby some producers are disadvantaged. We will return to this point, but for now let us record another objection. ${ }^{22}$ Crucially, trading relations do not per se entail special obligations. It does not seem that merely by trading with A we acquire duties we do not have towards B. While it would be desirable if everybody had certain wages, trade relations are not of the right sort to trigger associative obligations to see to this. In the case of subsidized farmers in the developed world, the claims-based argument relied on a shared coercive structure that had to be justifiable to all. Redistributive duties are then easier to establish than in the mere presence of trade. The unqualified version of this view fails.

Matters stand differently for a qualified version of the second view. If trade directly inflicts, or is otherwise causally involved in activities that inflict, wrongful harm, duties are generated. These are duties to rectify the harm inflicted and to stop inflicting it. This qualified version of the second view will be plausible enough, or so we assume, but the question becomes: what counts as wrongful harm? Some (libertarians) would say that unless one violates negative rights, one does no wrongful harm. Others would say that the whole global political and

22 Wolf puts it well, p 206: "Unfortunately, in the absence of supply management, the growth of privately organized schemes for 'fair trade' in primary commodities will not lead to the higher incomes their proponents desire. They may well raise prices for some producers, but if, as seems plausible, this leads to somewhat higher capacity, as additional investment is made in response to those prices, they will lower returns for everyone else. In practice, the fair-trade movement probably makes virtually no difference: less than 1 per cent of cocoa, tea and coffee sales are carried out on a fair-trade basis." However, a crucial phrase is "in the absence of supply management." So should one not argue instead that there should be such management? The subsequent discussion addresses that question. 
economic system inflicts such harm (cf. Shue (1980), Pogge (2002)). There are also intermediate views that argue trade is involved in wrongful harming if (among other things) gains from trade come at the expense of oppressed people, where "at the expense" refers to a relevant market comparison. ${ }^{23}$

It is because of the empirical plausibility of such intermediate views coming true for trade that one should not dismiss this qualified version by pointing out that any activity creates duties of rectification if involved in wrongful harming. While that is true, trade lends itself especially well to being part of patterns in which this is the case, because of its highly structured nature that, given appropriate political conditions, can easily come at the expense of parts of the population who are kept at a disadvantaged status so that others can harvest gains from trade. Arguably, such people have a complaint in fairness against trading partners, even if those are not involved in their plight other than by trading. Since duties to rectify wrongful harm and to stop doing it also have to be acknowledged on the first view, our discussion, having started off with two proposals of how to think about a consumer's duty in trade relations, has led to a unified view: trade does not create any associative duties, but is one way of satisfying duties that hold independently, except in cases in which it is involved in inflicting wrongful harm, when we have a duty to stop inflicting such harm and to rectify past unfairness.

8. There is no need to decide what should be regarded as wrongful harm. What matters is that, on this view of how we should think about duties that emerge for the consumer in the context of trade, there is a broad range of conditions under which she ought to reflect on the larger impact

\footnotetext{
${ }^{23}$ Cf. Risse (forthcoming). The difference to Pogge's (2002) view is that this view uses a world or regional market and thinks of a trade regime's coming "at the expense" of some people in reference to that; on Pogge's (2002) view, that world market reference could not be made because the market is itself morally dubious.
} 
of her choice, about what would be a good development strategy for the countries overall in which the producers are located who are supposed to benefit from Fair Trade. These conditions always apply when trade does not involve wrongful harming. For then there is generally nothing morally special about trading partners to begin with. Suppose now trade is involved in wrongful harming. Distinguish two cases. For case (a), suppose wrongful harm has been done not merely to particular producers, but to everybody, or many others, in the respective countries. For case (b), suppose wrongful harm is done (more or less) only to those producers. That the typical case will be that the harm is also done to others is true for views such as Pogge's (2002) according to which the global order per se constitutes wrongful harming. In that case, consumers ought indeed to think of Fair Trade as part of a development strategy. This might also be so in case (b), either if Fair Trade cannot be effective (think of oppressive regimes that do not allow for the preconditions of Fair Trade to emerge); or if on balance the best way of ending a form of oppression or harm in the long run is by supporting the development of the country overall.

This last point will be contested. However, what matters is that there is a broad range of cases where consumers ought to think of Fair Trade not just in relation to a set of producers, but as a development strategy, understand its impact on producers as well as other members of their communities and nations, and compare it to other such strategies. There will also be cases where Fair Trade matters per se, where merely or mostly the producers, rather than many others in the respective countries as well, are harmed, and where it seems unacceptable to address the problems by adopting a strategy that will benefit the development of the country overall. The precise contours of these sets of cases need not be ascertained. Crucially, in all cases of the first sort, Fair Trade must pass the test of being a sustainable development strategy, at any rate one superior to the available alternatives. This point poses a challenge because its defenders will 
have to argue that Fair Trade can indeed plausibly be seen as a promising development strategy (unless they want to restrict the range of cases under which they argue for Fair Trade purchases to those in which one does not have to ponder whether Fair Trade is such a strategy).

To make this concrete: Declining commodity prices reflect their unstable nature and the vulnerable position in which global competition places commodity producers. The volatility of commodity prices often combines with the far from lucrative nature of agriculture and raw materials to undermine producers' economic sustainability. Ensuring that people can make a decent living in commodities can set wrong incentives. It invites people to enter this business though they would be well-advised to do something else. ${ }^{24}$ By way of contrast, consider a case of a successful production shift. In Costa Rica a focus on new exports and eco-tourism allowed the country to diversify away from their previous staple exports, coffee and bananas. The export share of non-traditional products rose from $38.6 \%$ in 1982 to $87 \%$ in 2003 . Such a shift is a promising alternative to Fair Trade's strategy of keeping people in business. ${ }^{25}$

Fair Trade, then, cannot generally ask consumers to think just of their relationship with certain producers. Instead, often, the consumer will have to consider the impact of Fair Trade more broadly, as a development strategy, and Fair Trade would have to be defended as such. With this challenge in place, let us see how Fair Trade advocates could defend their view. According to a common defense, Fair Trade insists that its products are under-described merely as coffee, cocoa, bananas, etc. Instead, products should be described in terms of the conditions under which they are produced and the institutions and practices their purchase supports. Among

\footnotetext{
${ }^{24}$ On agriculture, cf. Tweeten and Thompson (2002), p.88. Leclair (2002) also takes this view. It should be noted that this argument can only be applied to cases where pursuing a different industry is possible, meaning that there are resources and opportunities to do so.

${ }^{25}$ Cf. Itzigsohn (2000), p 32. Cf. Finger and Nogues (2006), p 174; cf. also Sick (1999).
} 
those conditions are sustainable wages and a certain level of benefits, conditions that define the sort of working environment everyone should enjoy. When the history of production is seen as part of product descriptions, Fair Trade products are claimed not to sell above market price because their market is not one of other, say, coffee-beans, but one of products with these additional characteristics. Customers ought to buy these products because such purchases are their contributions to the creation of a fair world.

As this argument makes clear, Fair Trade attempts to induce consumers to perceive the purchase of goods as support of their production process and to differentiate among goods on the basis of that process. The purchase of a product also supports its production, and the externalities that surround it. By buying Nike shoes, one supports the Nike Corporation. By buying Fair Trade coffee, one supports labor conditions, sustainable farming methods and cooperatives that build infrastructure. ${ }^{26}$ Buying non-Fair Trade products means buying goods that may have been produced in non-sustainable ways, harvested for low wages or through child labor, and utilized environmentally unsustainable or harmful farming practices. Or so Fair Trade advocates argue. This argument can be developed both as an individual-claims-based argument and as a collective-preference-based argument. According to the former, farmers have a claim against consumers to buy their products because doing so contributes to a fair world, while not doing so contributes to an unfair one. Consumers ought to strive for the former, at any rate if it involves only a small sacrifice. According to the second argument, the claim would be that higher prices are justified as an expression of a collective preference.

\footnotetext{
${ }^{26}$ If it sounds odd to think of products as described in terms of their history, keep in mind that what counts as products on a market is not a naturally given fact. For instance, for a market in "wheat" to emerge (rather than a system in which Smith's and Jones' harvest would be assessed separately), a system of transporting wheat had to develop in which harvests of different quality were mixed with each other early on. This led to "wheat" per se as a product, as opposed to” Smith’s wheat” or “Jones’s wheat” (Cf. Pomeranz and Topik (2006), pp 186-188).
} 
9. Both of these versions of the argument for Fair Trade must be reconciled to the claim that, in a broad range of circumstances, consumers must think of Fair Trade as one possible development strategy. There are serious doubts that Fair Trade is such a strategy. Little is gained by promoting fairness before a certain level of economic development is reached; being concerned about fairness at an early stage of development can lock countries into current forms of production, preventing them from exploring alternatives. For instance, often countries should not rely on agriculture as a source of income. Agriculture is volatile and often unprofitable. Where individuals can viably pursue other industries and where Fair Trade provides them with an incentive not to do so, Fair Trade works to lock the country into existing low-returned industries and prevents them from exploring new industries, a course necessary to escape from poverty at a larger scale. Or, on a related point, consider efforts to improve working conditions. In a telling discussion, Wolf (2004) assesses efforts to improve working conditions in India,

where a combination of strong trade unions, job protection, reservation of production to small-scale enterprises and prohibition of closure of bankrupt plants has halted growth of employment in modern manufacturing. Today, employment in large-scale manufacturing is about 5 million people, in a country of over a billion. There is little chance of its rising significantly. India's industrialization has been blocked. Indian workers are so well protected from exploitation by industrial bosses that they have no jobs at all. The exact opposite happened in South Korea and Taiwan. Today, the workforces of these countries enjoy wages and conditions Indians can only dream of. The desirable development path goes via rapid growth of output and employment in a profitable modern sector to a tighter overall labor market. (p 187)

The general point is that, to the extent that a case can be made that trade has beneficial consequences in the long run, the consequences may outweigh current unfairness if it is sufficiently probable that other measures are taken to elicit those consequences. In his discussion on eradicating child labor, Wolf claims sanctions are "a way of penalizing [countries] for their poverty while taking away the best ladder out of it” (p 188). Such considerations suggest that, in 
cases where Fair Trade should be considered one development strategy among others, it will often not emerge as the best possible strategy. Fair Trade might be a set-back to development.

Advocates may respond that there are cases in which this conclusion does not hold. First of all, there are those cases we identified above where it is not the case that Fair Trade must be thought of as one among several development strategies, but instead as a way of rectifying particular injustices, and where it is implausible to argue that pursuing the overall development of the given country is the best way of addressing a particular injustice. Moreover, even in cases in which Fair Trade should be thought of as one among competing development strategies, it might happen, for instance, that individuals lack resources and alternatives to their current industries and their government lacks the resources to aid their transitioning out. ${ }^{27}$ In that case, Fair Trade would aid individuals and developing nations to gather necessary resources that will allow them to shift to more sustainable development projects and develop new industries.

So while there is a broad range of cases where Fair Trade is not a sensible development strategy; there are others where, given the alternatives, it is, and there are perhaps yet others in which it does not matter whether it is because it should be endorsed anyway. Yet crucially, the consumer is often in no position to make an informed decision about which of these is the case. Much depends on what other strategies are available, and on what else would happen if it were not for the presence of Fair Trade. The problem is not merely that individuals tend to be badly placed to gather the relevant information. The bigger problem is that even from a standpoint of the best understanding currently available, there may be no clear answer in many scenarios as to what is the best possible development strategy for a country. A complicating factor is that what counts as the best possible strategy is not merely an empirical question involving the assessment

\footnotetext{
27 "Power to the Poor." Greg Mock and Paul Steele, Environment, Jan/Feb2006, Vol. 48 Issue 1, p8-23, 16p, 3 charts, 1 diagram, 3 graphs, 6c;
} 
of counterfactuals, but also a normative question about for what development ought to aim. Fair Trade representatives try to spread information about their products and the conditions under which they are made. By informing consumers of the conditions that exist on coffee or banana farms that produce cheap goods, and of the environmental side-effects of such production, Fair Trade attempts to overcome the market's information failure and to show consumers that their purchase translates into support of one type of business. Nonetheless, it lacks the ability to inform customers about particular products that carry its mark and the circumstances surrounding a product that would determine whether the consumer ought to buy it. Furthermore, it may erroneously support producers who could and should transition out of their current sector.

So while sometimes there will be a rightful claim on consumers to buy Fair Trade products, other times there will not be. The consumer is generally in no position to distinguish one case from the other. As Fair Trade encompasses both scenarios, a consumer cannot be placed under a general duty to buy such products. The claims-based argument for Fair Trade fails. But are consumers nonetheless permitted to embrace Fair Trade as a preference? Does the collectivepreference-based version of this argument succeed? Since there are cases when the consumer ought not to embrace Fair Trade, it might seem that she should not see herself as generally permitted to buy Fair Trade products. Yet if so, she will fail to do so even when she ought to.

We can resolve this situation if we keep in mind that Fair Trade does not occupy large market shares. Consider coffee. While worldwide, sales of Fair Trade coffee have increased from $\$ 22.5 \mathrm{~m}$ per year to $\$ 87 \mathrm{~m}$ per year since 1998 , this is only a fraction of the overall world coffee trade, which is worth $\$ 10$ billion annually. ${ }^{28}$ In light of this small market share, little harm is done by supporting the movement, even when its support is not a good development strategy.

${ }^{28}$ C. “Fair Enough,” Economist, 4/1/2006, Vol. 378 Issue 8471, p33-33, 2/3p, 1c). 
Thus in cases in which one ought to support Fair Trade, one is anyway permitted, and in cases in which one is not, one does little harm to development while benefiting somebody immediately. Therefore, the collective-preference based argument succeeds. In the end, and presumably to the chagrin of Fair Trade Advocates, the permissibility of consumers to purchase Fair Trade hinges on the movement's improbability of hindering more feasible development strategies.

\section{Literature}

Anderson, Kym. 2004. “Subsidies and Trade Barriers.” In Bjorn Lomborg (ed.), Global Crises, Global Solutions. Cambridge: Cambridge University Press

Anderson, Kym, and Will Martin (eds.). 2006a. Agricultural Trade Reform and the Doha Development Agenda. Palgrave Macmillan and the World Bank

Anderson, Kym, and Will Martin. 2006b. “Agriculture, Trade Reform, and the Doha Agenda.” In Kym and Martin (2006a): pp 3-37

Bhagwati, Jagdish. 1993. "Fair Trade, Reciprocity, and Harmonization: the Novel Challenge to the Theory and Policy of Free Trade.” In Dominick Salvatore, Protectionism and World Welfare. Cambridge: Cambridge University Press

Birdsall, Nancy, Dani Rodrik, and Arvind Subramanian. 2005. "How to Help Poor Countries.” Foreign Affairs, July/August 2005

Blake, Michael. 2001. “Distributive Justice, State Coercion, and Autonomy.” Philosophy and Public Affairs 30: pp 257-297

Frank, Dana. 1999. Buy American: the untold story of economic nationalism. Boston: Beacon Press

Egan, Timothy. 2006. The Worst Hard Time: The Untold Story of Those Who Survived the Great American Dustbowl. Boston: Houghton Mifflin 
Finger, Michael and Julio Nogues. 2006. Safeguards and Antidumping in Latin American

Trade Liberalization: Fighting Fire with Fire. New York: The World Bank and Palgrave Macmillan.

Frank, Dana. Buy American: the untold story of economic nationalism. Boston: Beacon Press, 1999.

Hall, Peter, and David Soskice (eds.). 2001. Varieties of Capitalism: The Institutional Foundations of Comparative Advantage. Oxford: Oxford University Press

Hausmann, Ricardo, and Dani Rodrik. 2003. "Economic Development as SelfDiscovery.” Journal of Development Economics, vol. 72, December 2003.

Hertel, Thomas, and Roman Keeney. 2006. "What is at Stake: The Relative Importance of Import Barriers, Export Subsidies, and Domestic Support.” In Hertal and Keeney (2006a), pp $37-63$

Hoekman, Bernard, and Michel Kostecki. 2001. The Political Economy of the World Trading System. Oxford: Oxford University Press

Howell, Chris. 2003. "Review Article: Varieties of Capitalism. And Then There Was One?” Comparative Politics 36 (1): pp 103-125

Ingco, Merlinda and John Nash (eds). 2004. Agriculture and the WTO: Creating a Trading System for Development. Washington DC: The International Bank for Reconstruction and Development and The World Bank.

Irwin, Douglas 2002. Free Trade under Fire. Princeton: Princeton University Press

Jaffee, Daniel, Jack Kloppenburg, and Mario Monroy. 2004. "Bringing the 'Moral Charge' Home: Fair Trade Within the North and within the South.” Rural Sociology 69 (2): pp 169-196 
Itzigsohn, Jose. 2002. Developing Poverty. University Park: The Pennsylvania State University Press.

Kröhnert, Steffen, Franziska Medicus, und Reiner Klingholz. 2006. Die Demografische Lage der Nation: Wie Zukunftsfähig sind Deutschlands Regionen? München: Deutscher Taschenbuch Verlag

Krugman, Paul, and Maurice Obstfeld. 2003. International Economics. Theory and Policy (Sixth Edition). Boston: Addison Wesley

Leclair, Mark. 2002. "Fighting the Tide: Alternative Trade Organizations in the Era of Global Free Trade.” World Development 30: pp 949-958

Littrell, Mary Ann, and Marsha Ann Dickson. 1999. Social Responsibility and the Global Market: Fair Trade of Cultural Products. New York: Sage

Oxfam. 2002. Rigged Rules and Double Standards. Oxfam International

Panagariya, Arvind. 2003. “Think Again: International Trade.” Foreign Policy, November/December: pp 20-28

Panagariya, Arvind. 2004a. "Miracles and Debacles: in Defense of Trade Openness." World Economy 27 (8): pp 1149-1171

Panagariya, Arvind. 2004b. "Miracles and Debacles: Do Free-Trade Skeptics Have a Case?”; as of December 2004, at http:www.columbia.edu/ ap2231/policy.html

Panagariya, Arvind. 2005. "Agricultural Liberalization and the Least Developed Countries: Six Fallacies.” World Economy 28 (9): pp 1277-1299

Parfit, Derek. 1984. Reasons and Persons. Oxford: Oxford University Press

Pomeranz, Kenneth, and Steven Topik. 2006. The World that Trade Created. Society, Culture, and the World Economy, 1400 to the Present. London: M.E. Sharpe . 
Rawls, John. 1999. A Theory of Justice. $2^{\text {nd }}$ edition. Cambridge: Harvard University Press

Rawls, John. 2001. Justice as Fairness: A Restatement. Ed. by Erin Kelly. Cambridge: Harvard University

Risse, Mathias. Forthcoming. Fairness in Trade. Kennedy School of Government Working Paper, No. RWP05-004

Rodrik, Dani. 1999. The New Global Economy and Developing Countries: Making Openness Work. Baltimore: Johns Hopkins University Press

Rodriguez, Francisco, and Dani Rodrik. 2000. “Trade Policy and Economic Growth: A Skeptic's Guide to the Cross-National Evidence.” In: Ben Bernanke and Kenneth Rogoff, Macroeconomics Annual 2000. Cambridge: MIT Press

Sick, Deborah. 1999. Farmers of the Golden Bean: Costa Rican Households and the Global Coffee Economy. Dekalb: Northern Illinois University Press.

Stiglitz, Joseph. 2002. Globalization and Its Discontents. New York: Norton

Stiglitz, Joseph, and Andrew Charlton. 2006. Fair Trade for All. How Trade Can Promote Development. Oxford: Oxford University Press

Streeck, Wolfgang, and Kozo Yamamura (eds.). 2001. The Origins of Nonliberal Capitalism: Germany and Japan in Comparison. Ithaca: Cornell University Press

Trebilcock, Michael, and Robert Howse. 2005. The Regulation of International Trade. New York: Routledge

Tweeten, Luther and Stanley Thompson (eds). 2002. Agricultural Policy for the 21st Century. Ames: Iowa State Press 
USITC. 1997. The Dynamic Effects of Trade Liberalization: An Empirical Analysis, Investigation 332-375, Publication 3069, Washington D.C.: United States International Trade Commission

Wacziarg R. and K. H. Welch. 2003. "Trade Liberalization and Growth: New Evidence.” NBER Working Paper 10152, Cambridge (MA)

Watkins, Kevin, and Jung-ui Sul. 2002. "Cultivating Poverty: The Impact of US Cotton Subsidies on Africa.” Oxfam Briefing Paper

Winters, Alan, Neil McCulloch, and Andrew McKay. 2004. "Trade Liberalization and Poverty: The Evidence So Far.” Journal of Economic Literature 42, pp 72-115

Wolf, Martin. 2004. Why Globalization Works. New Haven: Yale University Press 